\title{
DILEMATIS ANTARA PEMASARAN TRADISIONAL DENGAN PEMASARAN DIGITAL TERKAIT PERUBAHAN PERILAKU KONSUMEN: STUDI PADA MASA PANDEMI COVID-19
}

\author{
Clarence $^{1}$, Yulianti ${ }^{2}$, Christian Halim ${ }^{3}$, Puspa Ratna Sari ${ }^{4}$, Keni Keni ${ }^{*}$ \\ ${ }^{1}$ Program Studi Manajemen Bisnis Universitas Tarumanagara Jakarta \\ Email: clarence.115180319@stu.untar.ac.id \\ ${ }^{2}$ Program Studi Manajemen Bisnis Universitas Tarumanagara Jakarta \\ Email: yulianti.115180306@stu.untar.ac.id \\ ${ }^{3}$ Program Studi Manajemen Bisnis Universitas Tarumanagara Jakarta \\ Email: christian.115180339@stu.untar.ac.id \\ ${ }^{4}$ Program Studi Desain Komunikasi Visual Universitas Tarumanagara Jakarta \\ Email: puspa.625180070@stu.untar.ac.id \\ ${ }^{5}$ Program Magister Manajemen Bisnis Universitas Tarumanagara Jakarta \\ Email:keni@fe.untar.ac.id \\ *penulis korespondensi
}

Masuk : 08-09-2021, revisi: 16-09-2021, diterima untuk diterbitkan : 16-09-2021

\begin{abstract}
ABSTRAK
Niat membeli dapat dipengaruhi oleh pemasaran tradisional maupun digital. Penelitian ini memiliki tujuan untuk mengetahui pengaruh pemasaran tradisional dan digital, serta efek moderasi pandemi Covid-19 terhadap niat membeli vitamin. Dalam penelitian ini, sampel yang terkumpul sebanyak 245 responden yang diperoleh dari kuesioner yang dibagikan secara online melalui google form. Untuk analisis data, penelitian ini menggunakan Partial Least Square - Structural Equation Modeling (PLS-SEM) dengan bantuan software SmartPLS. Hasil penelitian ini menunjukkan bahwa pemasaran tradisional dan digital memiliki pengaruh terhadap niat membeli. Sementara itu, pemasaran tradisional yang dimoderasi oleh pandemi Covid-19 tidak memiliki pengaruh terhadap niat membeli, namun hasil yang berbeda untuk pemasaran digital dimana pandemi Covid-19 memoderasi hubungan antara pemasaran digital dan niat membeli.
\end{abstract}

Kata kunci: Niat Membeli, Pemasaran Tradisional, Pemasaran Digital, Covid-19

\section{ABSTRACT}

Purchase intention can be influenced by both traditional and digital marketing. This study aims to determine the effect of traditional and digital marketing, as well as the moderating effect of the Covid-19 pandemic on the intention to buy vitamins. In this study, the sample collected was 245 respondents obtained from questionnaires distributed online via google form. For data analysis, this study uses Partial Least Square - Structural Equation Modeling (PLS-SEM) with SmartPLS software. The results of this study indicate that traditional and digital marketing have an influence on purchase intention. Meanwhile, traditional marketing moderated by the Covid-19 pandemic had no effect on purchase intention, but the results were different for digital marketing where the Covid19 pandemic moderated the relationship between digital marketing and purchase intention.

Keywords: Purchase Intention, Traditional Marketing, Digital Marketing, Covid-19

\section{PENDAHULUAN \\ Latar Belakang}

Situasi pandemi Covid-19 membawa perubahan terhadap perilaku konsumen salah satunya yaitu niat membeli, dimana hal tersebut membuat konsumen lebih peduli akan kesehatan. Hasil survei dari PwC Indonesia menunjukkan bahwa terdapat peningkatan belanja konsumen di Indonesia pada produk kesehatan sebesar 77\%. Berbagai macam produk di bidang kesehatan mulai dicari dan dibeli oleh konsumen, salah satunya yaitu vitamin. Halodoc menyatakan bahwa selama masa pandemi penjualan vitamin mengalami kenaikan sebesar 174\%. Angka tersebut menunjukkan bahwa terdapat peningkatan niat membeli vitamin yang dipengaruhi oleh pemasaran, baik secara 
tradisional maupun digital. Penelitian ini mengacu pada Theory Reasoned Action (TRA) yang mengasumsikan bahwa manusia berperilaku secara sadar dan mempertimbangkan segala informasi yang tersedia (Ajzen, 1975). Teori ini menjelaskan bahwa niat menjadi faktor yang mempengaruhi terjadinya suatu tindakan. Faktor-faktor yang mempengaruhi niat tersebut adalah faktor pribadi dan faktor sosial. Kedua faktor tersebut memberikan pengaruh positif untuk memunculkan sebuah niat yang menyebabkan individu melakukan tindakan dalam berperilaku.

Seperti yang kita sadari bahwa pemasaran tradisional telah ada dan digunakan sebelum adanya pemasaran digital. Todur (2016) mendefinisikan pemasaran tradisional sebagai alat untuk menimbulkan niat membeli melalui bentuk yang berwujud, seperti kartu nama, poster, serta media cetak di majalah dan surat kabar. Sampai saat ini, tidak sedikit pelaku usaha yang menggunakan pemasaran tradisional untuk memasarkan suatu produk untuk menimbulkan niat membeli. Hal tersebut menjadikan pemasaran tradisional tidak ditinggalkan begitu saja, terlebih pada perkembangan zaman yang memudahkan konsumen dalam menggunakan internet.

Peningkatan pengguna internet di Indonesia telah memotivasi pelaku usaha untuk mengubah teknik pemasarannya dari tradisional menjadi digital untuk beradaptasi dengan perilaku konsumen yang pada saat ini lebih cenderung untuk berbelanja secara online (Jundrio \& Keni, 2020; Maria, Wijaya dan Keni, 2021). Sawicki (2016) mendeskripsikan pemasaran digital sebagai bentuk eksplorasi dalam dunia teknologi digital secara luas yang menciptakan platform untuk menghubungkan pembeli yang potensial. Pemasaran digital digunakan untuk mempromosikan keunggulan produk dan menjadi sarana yang efektif dan efisien dalam berkomunikasi dengan konsumen. Hal ini juga seiring dengan tingginya minat masyarakat Indonesia terhadap pemasaran digital. Hootsuite (We are Social) Indonesian Digital Report 2021 menyatakan bahwa pengguna internet di Indonesia mencapai $73,7 \%$ dari jumlah penduduk, yang membuat pemasaran digital tepat untuk digunakan.

Dalam menentukan saluran pemasaran tradisional atau digital masih terdapat pandangan yang berbeda. Banyak pelaku usaha yang menilai bahwa pemasaran tradisional lebih efektif dibandingkan pemasaran digital dalam mempengaruhi niat membeli konsumen, begitupun juga sebaliknya. Untuk menentukan saluran pemasaran yang tepat, hal ini didasarkan pada kebutuhan pelaku usaha.

Berdasarkan uraian di atas, maka tujuan dari penelitian ini adalah untuk menguji: (1) pengaruh pemasaran tradisional terhadap niat membeli, (2) pengaruh pemasaran digital terhadap niat membeli, (3) hubungan pemasaran tradisional dengan niat membeli yang dimoderasi pandemi Covid-19, dan (4) hubungan pemasaran digital dengan niat membeli yang dimoderasi pandemi Covid-19. Penelitian ini diharapkan dapat memberikan manfaat bagi pelaku usaha yaitu berupa pemahaman untuk menentukan saluran strategi pemasaran yang tepat. Selain itu, bagi kalangan akademis maupun umum, penelitian ini juga diharapkan dapat memberikan pengetahuan, pemahaman, serta sebagai referensi untuk peneliti berikutnya yang membahas tentang pemasaran tradisional, pemasaran digital, dan niat membeli konsumen.

\section{Rumusan Masalah}

Dari uraian latar belakang di atas, maka rumusan masalah dalam penelitian ini sebagai berikut:

1. Apakah terdapat pengaruh pemasaran tradisional terhadap niat membeli?

2. Apakah terdapat pengaruh pemasaran digital terhadap niat membeli?

3. Apakah pandemi Covid-19 memoderasi hubungan antara pemasaran tradisional dengan niat membeli? 
4. Apakah pandemi Covid-19 memoderasi hubungan antara pemasaran digital dengan niat membeli?

\section{Telaah Kepustakaan \\ Pemasaran Tradisional}

Todur (2016) mendefinisikan pemasaran tradisional sebagai alat untuk menimbulkan niat membeli melalui bentuk yang berwujud, seperti kartu nama, poster, serta media cetak di majalah dan surat kabar. Zarrella (2010) menambahkan bahwa alat pemasaran tradisional dapat berupa televisi, koran, radio, dan majalah yang dianggap sebagai teknologi penyiaran yang bersifat satu arah dan statis. Wongleedee (2015) menyatakan bahwa pemasaran tradisional merupakan lingkungan yang sangat kompetitif bagi pelaku usaha, sehingga mereka harus mampu bersaing. Dengan demikian, dapat disimpulkan bahwa pemasaran tradisional merupakan teknik pemasaran klasik yang menampilkan iklan di televisi, radio, koran, dan media lainnya.

\section{Pemasaran Digital}

García et al. (2019) mendefinisikan pemasaran digital sebagai teknik baru di bidang pemasaran dalam bentuk online dengan mempengaruhi konsumen melalui berbagai saluran interaksi, seperti media sosial, aplikasi seluler, blog, email, dan bahkan optimisasi mesin pencari (SEO). Hal tersebut sejalan dengan pendapat Kotler (2017) yang menyatakan bahwa pemasaran digital sebagai sub proses pemasaran dimana organisasi dan pelanggan menggunakan internet untuk menciptakan nilai pada suatu produk. Sawicki (2016) juga mendeskripsikan pemasaran digital sebagai bentuk eksplorasi dalam dunia teknologi digital secara luas yang menciptakan platform untuk menghubungkan pembeli yang potensial. Dengan demikian, dapat disimpulkan bahwa pemasaran digital merupakan salah satu bentuk atau cara untuk memasarkan produk dalam bentuk online, yang dapat diakses melalui internet seperti media sosial, blog, dan lainnya.

\section{Niat Membeli}

Kotler dan Keller (2016) menyatakan bahwa perilaku konsumen merupakan studi yang membahas bagaimana individu, kelompok, dan organisasi dalam memilih, membeli dan menggunakan produk. Menurut Schiffman et al. (2016) niat membeli mengacu pada komponen konatif pada sikap dimana terdapat kemungkinan konsumen melakukan pembelian produk tertentu. Selain itu, Fenetta dan Keni (2020) berpendapat bahwa niat beli terjadi ketika seorang konsumen ingin melakukan pembelian produk karena suatu motivasi tertentu. Dengan demikian, dapat disimpulkan bahwa niat membeli adalah sebuah proses untuk melakukan pembelian yang didasarkan pada pertimbangan tertentu.

\section{Pandemi Covid-19}

Pandemi Covid-19 merupakan virus berbahaya yang telah menyebar di seluruh dunia yang dideklarasikan pada 9 Maret 2020 oleh WHO (World Health Organization). Pandemi tersebut dapat menyebabkan gejala ringan atau sedang, namun pada beberapa orang dapat menyebabkan gejala yang berat dikarenakan kondisi fisik yang lemah, terdapat penyakit bawaan, serta faktor usia masyarakat (Kumar \& Somani, 2020). Oleh sebab itu, secara tidak langsung, pandemi Covid-19 menimbulkan rasa takut, cemas, dan tidak berdaya yang berpengaruh terhadap kondisi kesehatan psikologis masyarakat (Qiu et al., 2018). Pandemi Covid-19 menyebabkan para pelaku usaha lebih menggencarkan pemasarannya dan terjadi perubahan pada perilaku konsumen dalam niat membeli produk kesehatan. 


\section{Kaitan antara Pemasaran Tradisional dan Niat Membeli}

Hasil penelitian Fatima \& Idress (2020) menunjukkan bahwa niat membeli konsumen sangat dipengaruhi oleh iklan TV. Hal tersebut juga didukung oleh Khuong \& Nguyen (2015) yang menyatakan bahwa iklan di TV dapat meningkatkan minat dan tindakan konsumen untuk membeli, dimana iklan TV merupakan salah satu bagian dari pemasaran tradisional. Pemasaran tradisional yang menarik akan menimbulkan kesenangan tersendiri, misalnya merasa terhibur dan lain sebagainya. Hal ini tentunya dapat merangsang konsumen sehingga menimbulkan niat membeli. Berdasarkan uraian di atas, hipotesis dari penelitian ini adalah sebagai berikut:

H1: Pemasaran tradisional memiliki pengaruh terhadap niat membeli konsumen.

\section{Kaitan antara Pemasaran Digital dan Niat Membeli}

Hasil penelitian yang dilakukan oleh Dastane (2020) menunjukkan adanya pengaruh pemasaran digital terhadap niat membeli secara positif dan signifikan. Khan dan Bilal (2020) menyatakan bahwa pemasaran digital berpengaruh secara positif dan signifikan terhadap niat membeli. Menurut Pandey (2020), pemasaran digital berpengaruh positif terhadap perilaku konsumen dalam membeli karena mengikuti perkembangan zaman, ekonomis dan lebih efektif. Berdasarkan uraian di atas, hipotesis dari penelitian ini adalah sebagai berikut:

H2: Pemasaran digital memiliki pengaruh terhadap niat membeli konsumen.

\section{Pandemi Covid-19 Memoderasi Kaitan antara Pemasaran Tradisional dan Niat Membeli}

Pandemi Covid-19 menyebabkan perubahan bagi kehidupan masyarakat, dimana mereka dihimbau untuk tetap berada di rumah. Aktivitas yang dilakukan di rumah, seperti menonton televisi, dijadikan sebagai peluang oleh para pelaku usaha untuk melakukan pemasaran di televisi yang diharapkan dapat menimbulkan niat membeli suatu produk. Dengan adanya pemasaran tradisional yang menarik dalam menyajikan informasi selama pandemi Covid-19 dapat menciptakan niat membeli pada konsumen. Berdasarkan uraian di atas, hipotesis dari penelitian ini adalah sebagai berikut:

H3: Pandemi Covid-19 memoderasi hubungan antara pemasaran tradisional dengan niat membeli.

\section{Pandemi Covid-19 Memoderasi Kaitan antara Pemasaran Digital dan Niat Membeli}

Aktivitas yang dilakukan masyarakat di rumah selama pandemi Covid-19 selain menonton televisi, yaitu aktif dalam menggunakan teknologi digital untuk mengakses media sosial, youtube, dan lain sebagainya. Hal tersebut dijadikan sebagai peluang oleh pelaku usaha untuk memasarkan produk menggunakan teknologi digital. Pemasaran digital dirasa cukup efektif untuk menimbulkan niat membeli konsumen selama pandemi Covid-19. Berdasarkan uraian di atas, hipotesis dari penelitian ini adalah sebagai berikut:

H4: Pandemi Covid-19 memoderasi hubungan antara pemasaran digital dengan niat membeli.

Berdasarkan penjelasan kaitan antar variabel, maka gambaran model dari penelitian ini adalah sebagai berikut: 


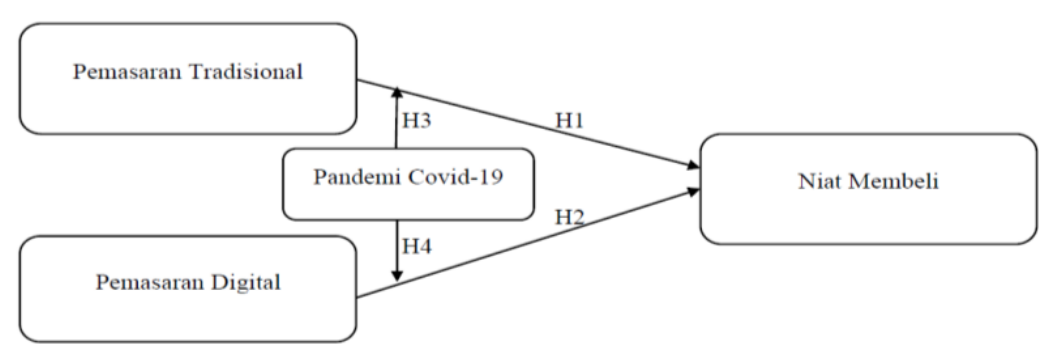

Gambar 1. Model Penelitian

\section{METODE PENELITIAN}

Desain penelitian deskriptif digunakan untuk memperoleh gambaran mengenai pemasaran tradisional dan pemasaran digital terhadap perubahan perilaku konsumen, khususnya dalam penelitian ini adalah niat membeli selama pandemi Covid-19. Dalam penelitian ini, pengumpulan data dilakukan dengan menyebarkan kuesioner yang bersifat terbuka dan tertutup yang dibagikan secara online melalui google form yang dilakukan selama 5 hari. Sampel dalam penelitian ini merupakan konsumen vitamin sebanyak 245 responden, namun terdapat 63 kuesioner yang tidak dapat digunakan dalam penelitian ini dikarenakan tidak sesuai dengan kriteria penelitian. Berdasarkan data yang dikumpulkan tersebut, jenis kelamin didominasi oleh wanita $(76,5 \%)$, usia 17-25 tahun $(91,6 \%)$, pekerjaan sebagai mahasiswa $(83,2 \%)$, pengeluaran per bulan untuk membeli vitamin sebesar kurang dari Rp200.000 (62,6\%), dan domisili di Jakarta (26,3\%). Kriteria dan pemberian skor pada kuesioner, yaitu (1) Sangat Tidak Setuju, (2) Tidak Setuju, (3) Netral, (4) Setuju dan (5) Sangat Setuju. Analisis data menggunakan pendekatan partial least square-structural equation modeling (PLS-SEM) dengan bantuan software SmartPLS.

Tabel 1. Measurement Scales

\begin{tabular}{|c|c|c|}
\hline Variabel & Pernyataan & Sumber \\
\hline \multirow{5}{*}{$\begin{array}{l}\text { Pemasaran } \\
\text { Tradisional }\end{array}$} & Saya pernah melihat iklan vitamin di televisi & \multirow{5}{*}{$\begin{array}{l}\text { Tumer et al. } \\
\text { (2019) }\end{array}$} \\
\hline & $\begin{array}{l}\text { Iklan vitamin di televisi memberikan informasi yang menarik } \\
\text { perhatian saya }\end{array}$ & \\
\hline & Iklan vitamin di televisi memberikan informasi yang jelas & \\
\hline & $\begin{array}{l}\text { Dengan adanya iklan di televisi membuat saya yakin bahwa } \\
\text { vitamin merupakan vitamin yang tepat }\end{array}$ & \\
\hline & $\begin{array}{l}\text { Iklan vitamin di televisi menjadi pilihan yang efektif dalam } \\
\text { membangun strategi pemasaran }\end{array}$ & \\
\hline \multirow{5}{*}{$\begin{array}{l}\text { Pemasaran } \\
\text { Digital }\end{array}$} & $\begin{array}{l}\text { Melalui iklan di media sosial, saya merasa yakin bahwa } \\
\text { vitamin merupakan produk vitamin yang tepat }\end{array}$ & \multirow{5}{*}{$\begin{array}{c}\text { Dastane, O } \\
(2020) \\
\text { Yuvaraj dan } \\
\text { Indumathi } \\
\text { (2018) }\end{array}$} \\
\hline & $\begin{array}{l}\text { Iklan vitamin di media sosial memberikan informasi yang } \\
\text { jelas }\end{array}$ & \\
\hline & $\begin{array}{l}\text { Media sosial memudahkan saya dalam membandingkan } \\
\text { produk vitamin dengan kompetitor }\end{array}$ & \\
\hline & Iklan vitamin di media sosial memberikan informasi terbaru & \\
\hline & Iklan vitamin di media sosial menarik perhatian saya & \\
\hline \multirow{4}{*}{$\begin{array}{l}\text { Niat } \\
\text { Membeli }\end{array}$} & $\begin{array}{l}\text { Saya memilih untuk membeli vitamin ini dibandingkan } \\
\text { dengan merek vitamin lainnya }\end{array}$ & \multirow{4}{*}{$\begin{array}{c}\text { Tumer } \text { et al. } \\
\text { (2019) } \\
\text { Dastane, O } \\
\text { (2020) }\end{array}$} \\
\hline & $\begin{array}{l}\text { Rekomendasi dari orang lain menimbulkan niat saya untuk } \\
\text { membeli vitamin }\end{array}$ & \\
\hline & Saya memiliki niat yang tinggi untuk membeli vitamin & \\
\hline & Pada saat ini, saya berencana untuk membeli vitamin & \\
\hline
\end{tabular}


Saya akan membeli vitamin di masa yang akan datang Selama pandemi Covid-19, saya banyak melihat iklan di televisi, koran, majalah dan media lainnya

Selama pandemi Covid-19, saya banyak melihat iklan di

Covid-19 media sosial, blog, dan lainnya

Selama pandemi Covid-19, saya suka berbelanja

Nguyen et al. (2020)

Saya memiliki niat membeli vitamin yang tinggi selama pandemi Covid-19

Saya membeli vitamin selama pandemi Covid-19

\section{HASIL DAN PEMBAHASAN}

\section{Hasil Uji Outer Model}

Pengujian outer model dilakukan untuk mengetahui validitas dan reliabilitas. Hasil pengujian outer model disajikan pada tabel berikut:

Tabel 2.Hasil Analisis Loading Factor

\begin{tabular}{lcccc}
\hline & Covid-19 & Digital & Niat Membeli & Tradisional \\
\hline C2 & 0,735 & & & \\
\hline C4 & 0,874 & & & \\
\hline C5 & 0,871 & & & \\
\hline D1 & & 0,767 & & \\
\hline D2 & 0,765 & & \\
\hline D3 & 0,724 & & \\
\hline D4 & 0,812 & & \\
\hline D5 & 0,822 & 0,828 & 0,849 \\
\hline N1 & & 0,862 & 0,744 \\
\hline N3 & & 0,751 & 0,847 \\
\hline N4 & & & \\
\hline N5 & & & \\
\hline T2 & & & \\
\hline T4 & & & \\
\hline T5 & & & \\
\hline
\end{tabular}

Setiap variabel memiliki 5 indikator. Menurut Hair et al. (2014), loading factor dari setiap indikator >0,7. Dengan demikian, variabel moderasi Covid-19 (C) memiliki 2 indikator yang tidak valid yaitu $\mathrm{C} 1(0,597)$ dan $\mathrm{C} 3(0,433)$, semua indikator dalam variabel pemasaran digital (D) valid, variabel niat membeli $(\mathrm{N})$ memiliki 1 indikator yang tidak valid yaitu $\mathrm{N} 2(0,664)$, dan variabel pemasaran tradisional $(\mathrm{T})$ memiliki 1 indikator yang tidak valid yaitu $\mathrm{T} 1(0,596)$.

Tabel 3. Hasil Analisis Construct Reliability and Validity

\begin{tabular}{cc}
\hline Variabel & Average Variance Extracted (AVE) \\
\hline Covid-19 & 0,688 \\
\hline Digital & 0,606 \\
\hline Niat Membeli & 0,688 \\
\hline Tradisional & 0,644 \\
\hline
\end{tabular}


Menurut Hair et al. (2014), nilai AVE valid jika lebih dari 0,5 (>0,5). Dari tabel di atas menunjukkan semua nilai AVE telah memenuhi syarat.

Tabel 4. Hasil Analisis Heterotrait-Monotrait Ratio (HTMT)

\begin{tabular}{ccccc}
\hline Variabel & Covid-19 & Digital & Niat Membeli & Tradisional \\
\hline Covid-19 & & & & \\
\hline Digital & 0,599 & & & \\
\hline Niat Membeli & 0,588 & 0,710 & & \\
\hline Tradisional & 0,557 & 0,753 & 0,656 & \\
\hline
\end{tabular}

Menurut Christian et al. (2015), suatu konstruk memiliki validitas diskriminan yang baik jika nilai HTMT lebih besar dari 0,9. Jika dilihat dari hasil pengolahan data, maka dapat dikatakan bahwa semua hasil memiliki validitas diskriminan yang baik.

Tabel 5. Hasil Analisis Cronbach's Alpha dan Composite Reliability

\begin{tabular}{cccc}
\hline Variabel & Cronbach's Alpha & Composite Reliability & Keterangan \\
\hline Covid-19 & 0,769 & 0,868 & Reliabel \\
\hline Digital & 0,839 & 0,885 & Reliabel \\
\hline Niat Membeli & 0,848 & 0,898 & Reliabel \\
\hline Tradisional & 0,816 & 0,878 & Reliabel \\
\hline
\end{tabular}

Menurut Sekaran dan Bougie (2016), nilai cronbach's alpha $>0,6$ dikatakan reliabel dan nilai composite reliability harus $>0,7$ (Ghozali, 2015). Dari hasil pengolahan data di atas, maka dapat dilihat bawah composite reliability $>0,7$ dan cronbach's alpha $>0,6$ sehingga memenuhi syarat atau kriteria.

\section{Hasil Uji Inner Model}

Pengujian inner model dilakukan untuk mengetahui hubungan antar variabel. Hasil pengujian inner model disajikan pada tabel berikut:

Tabel 6. Analisis Uji R Square

\begin{tabular}{ccc}
\hline Keterangan & R Square & R Square Adjusted \\
\hline Niat Membeli & 0,498 & 0,484 \\
\hline
\end{tabular}

Analisis $\mathrm{R}^{2}$ diuji untuk melihat seberapa besar variabel pemasaran tradisional dan pemasaran digital mampu menjelaskan variabel niat membeli. Nilai $\mathrm{R}^{2}$ sebesar 0,498 , artinya sebesar $49,8 \%$ dari variabel niat membeli dapat dijelaskan oleh pemasaran tradisional dan digital dan sisanya $50,2 \%$ dijelaskan oleh variabel lainnya.

Tabel 7. Uji Q Square

\begin{tabular}{cc}
\hline Keterangan & $\mathbf{Q}^{2}(=\mathbf{1}-\mathbf{S S E} / \mathbf{S S O})$ \\
\hline Niat Membeli & 0,325 \\
\hline
\end{tabular}

Nilai $\mathrm{Q}^{2}>0$ mengindikasikan model memiliki nilai relevansi prediktif, sementara nilai $\mathrm{Q}^{2}<0$ menunjukkan bahwa model kurang memiliki relevansi prediktif (Ghozali, 2011). Dari pengolahan data di atas, maka dapat disimpulkan model memiliki nilai relevansi prediktif. 


\section{Goodness of Fit}

Goodness of Fit dapat dicari dengan rumus (Tenenhaus, et al. 2004):

$$
\begin{gathered}
\text { GoF: } \sqrt{\overline{A V E} \times \overline{R^{2}}} \\
\text { GoF: } \sqrt{\overline{0,657} \times \overline{0,498}}
\end{gathered}
$$

GoF: 0,572

Menurut Wetzels et al. (2009), ketentuan dari GoF small yaitu 0,1, GoF medium yaitu 0,25 dan GoF large yaitu 0,36. Dengan demikian, dapat dikatakan bahwa dari hasil perhitungan termasuk GoF large.

Tabel 8. Hasil Uji Analisis f Square

\begin{tabular}{ccc}
\hline Keterangan & Niat Membeli & Pengaruh \\
\hline $\mathrm{D}^{*} \mathrm{C}$ & 0,053 & Lemah \\
\hline Digital & 0,163 & Sedang \\
\hline Niat Membeli & & \\
\hline $\mathrm{T}^{*} \mathrm{C}$ & 0,004 & Tidak ada \\
\hline Tradisional & 0,068 & Lemah \\
\hline
\end{tabular}

Nilai f square 0,02 sebagai kecil, 0,15 sebagai sedang, dan nilai 0,35 sebagai besar. Nilai kurang dari 0,02 bisa diabaikan atau dianggap tidak ada efek (Sarstedt et al., 2017).

Tabel 9. Hasil Pengujian Hipotesis

\begin{tabular}{ccccc}
\hline Keterangan & $\begin{array}{c}\text { Original } \\
\text { Sample }\end{array}$ & t-statistic & p-values & Hasil Pengujian \\
\hline Digital -> Niat membeli & 0,385 & 4,584 & 0,000 & Diterima \\
\hline Tradisional -> Niat membeli & 0,247 & 3,314 & 0,001 & Diterima \\
\hline $\mathrm{D}^{*} \mathrm{C}$-> Niat membeli & 0,189 & 2,552 & 0,011 & Diterima \\
\hline $\mathrm{T}^{*} \mathrm{C}$-> Niat membeli & $-0,052$ & 0,714 & 0,475 & Ditolak \\
\hline
\end{tabular}

\section{Pembahasan}

Berdasarkan pengujian hipotesis pada Tabel 9 di atas, diketahui bahwa pemasaran tradisional memiliki pengaruh positif terhadap niat membeli dengan path coefficient sebesar 0,247, yang membuktikan bahwa hipotesis $\left(\mathrm{H}_{1}\right)$ diterima. Hasil tersebut sejalan dengan penelitian yang telah dilakukan oleh Khuong \& Nguyen (2015) dan Fatima \& Idress (2020) yang menunjukkan bahwa pemasaran tradisional, khususnya iklan di televisi dapat meningkatkan niat membeli konsumen. Oleh karena itu, iklan di televisi dapat menjadi salah satu alternatif dan alat yang efektif memasarkan produk. Dengan adanya iklan di televisi, dapat membuat konsumen sadar dengan produk tersebut, kemudian tertarik dan memiliki niat membeli.

Untuk pengujian hipotesis berikutnya (H2), menunjukkan hasil bahwa pemasaran digital berpengaruh secara positif terhadap niat membeli dengan path coefficient sebesar 0,385 , yang membuktikan bahwa hipotesis (H2) diterima. Hasil tersebut sejalan dengan penelitian yang telah dilakukan Khan \& Bilal (2020), Dastane (2020), dan Pandey (2020) yang menunjukkan bahwa pemasaran digital berpengaruh positif terhadap niat membeli. Kemajuan teknologi saat ini telah meningkatkan penggunaan media sosial. Bagi pelaku usaha, hal ini dapat dijadikan sebagai peluang untuk mempromosikan produknya melalui media digital, seperti media sosial dengan 
membuat iklan yang menarik sehingga dapat meningkatkan niat membeli konsumen atas produk tersebut.

Selanjutnya hasil pengujian hipotesis (H3), menunjukkan bahwa pandemi Covid-19 tidak memoderasi dan memiliki hubungan negatif antara pemasaran tradisional dengan niat membeli dengan path coefficient sebesar -0,052. Menurut Triyoga dan Sodiq (2021), hal tersebut disebabkan karena selama pandemi Covid-19 terjadi peningkatan biaya produksi iklan di televisi dan beberapa stasiun televisi tidak memproduksi program baru sehingga mengurangi minat masyarakat untuk menonton televisi.

Hasil pengujian hipotesis berikutnya (H4), menunjukkan bahwa pandemi Covid-19 memoderasi dan memiliki hubungan positif antara pemasaran digital dengan niat membeli 0,189. Hasil penelitian ini sejalan dengan Omar (2021) yang menunjukkan bahwa pandemi Covid-19 memiliki pengaruh terhadap pemasaran digital. Hal tersebut disebabkan karena biaya untuk memproduksi iklan meningkat, sehingga banyak pelaku usaha yang mulai beralih memasarkan produknya melalui pemasaran digital, salah satunya di media sosial. Selain itu, hal ini didukung juga oleh masyarakat yang menghabiskan waktu lebih banyak di media digital terlebih selama pandemi Covid-19.

\section{KESIMPULAN DAN SARAN}

Terdapat perubahan perilaku konsumen dalam niat membeli yang dipengaruhi oleh pemasaran tradisional dan pemasaran digital selama pandemi Covid-19. Dari hasil penelitian yang telah dilakukan dapat disimpulkan bahwa pemasaran tradisional memiliki pengaruh positif dan signifikan terhadap niat membeli konsumen, pandemi Covid-19 tidak memoderasi dan memiliki hubungan negatif antara pemasaran tradisional dengan niat membeli, pemasaran digital memiliki pengaruh secara positif dan signifikan terhadap niat membeli konsumen, dan pandemi Covid-19 memoderasi hubungan antara pemasaran digital dengan niat membeli.

Peneliti menyarankan agar pelaku usaha dapat menentukan saluran strategi pemasaran yang tepat. Untuk saat ini, dirasa pemasaran digital dapat menjadi saluran yang efektif untuk memasarkan produk karena didukung oleh perkembangan zaman yang semakin mudah dalam mengakses dan mendapatkan informasi secara digital. Selain itu, banyaknya jumlah masyarakat yang menggunakan media digital, seperti media sosial menjadi salah satu faktor pendukung lainnya. Oleh karena itu, pelaku usaha dapat menggunakan saluran strategi pemasaran digital.

\section{Ucapan Terima Kasih}

Kami mengucapkan terima kasih kepada Tuhan Yang Maha Esa atas berkat dan rahmat-Nya dalam menyertai kegiatan penelitian. Selain itu, kami juga mengucapkan terima kasih kepada Kementerian Pendidikan dan Kebudayaan yang telah mengadakan acara dan memberikan hibah dana penelitian. Tidak lupa, kami juga mengucapkan terima kasih kepada pihak Universitas Tarumanagara, khususnya Fakultas Ekonomi dan Bisnis Jurusan Manajemen yang telah memberikan kesempatan untuk mengikuti Program Kreativitas Mahasiswa (PKM) 2021, serta dosen pembimbing yang senantiasa memberikan dukungan dan arahan dalam melakukan penelitian. Terima kasih juga kami ucapkan kepada seluruh pihak yang telah terlibat dan membantu dalam proses pembuatan penelitian ini. 


\section{REFERENSI}

Beneke, J., de Sousa, S., Mbuyu, M., \& Wickham, B. (2016). The effect of negative online customer reviews on brand equity and purchase intention of consumer electronics in South Africa. The International Review of Retail, Distribution and Consumer Research, 26(2), 171-201.

Brinson, N. H., \& Holiday, S. (2021). Understanding the influence of perceived susceptibility to addressable TV advertising targeting children on parents' purchase intentions. Young Consumer.

Christian, et al. (2015). A new criterion for assessing discriminant validity in variance-based structural equation modeling. Journal of the Academy of Marketing Science, 43(1), 115135.

Dastane, O. (2020). Impact of Digital Marketing on Online Purchase Intention: Mediation Effect of Customer Relationship Management. Journal of Asian Business Strategy. 10 (1), $142-$ 158.

Fatima, B., \& Idrees, M.A. (2020). Impact of Excessive T.V Commercials on Purchase Intention. Indus Journal of Management Sciences (IJMS), 1(1), 1-15.

Fenetta, A. \& Keni. (2020). Pengaruh Brand Awareness dan Perceived Quality terhadap Purchase Intention: Brand Loyalty sebagai Variabel Mediasi. Jurnal Manajemen Bisnis dan Kewirausahaan, 4(6), 270-275.

Ghozali, I. (2011). Aplikasi Analisis Multivariate dengan Program IBM SPSS 23. Badan Penerbit Universitas Diponegoro. Semarang.

Ghozali, I. (2015). Aplikasi Analisis Multivariate dengan Program IBM SPSS 23. Badan Penerbit Universitas Diponegoro. Semarang.

Hair, et al. (2011). PLS-SEM: indeed a silver bullet. Journal of Marketing Theory and Practice, $19(2), 139-151$

Hair, et al. (2014). Multivariate Data Analysis, New International Edition. Pearson Education Limited. New Jersey.

Hidayatullah, T. (2020). Penonton dan pengiklan di TV mulai beralih. URL: https://lokadata.id/artikel/penonton-dan-pengiklan-di-tv-mulai-beralih. Diakses tanggal 16 Agustus 2021.

Jundrio, H. \& Keni. (2020). Pengaruh Website Quality, Website Reputation dan Perceived Risk terhadap Purchase Intention pada Perusahaan E-Commerce. Jurnal Muara Ilmu Ekonomi dan Bisnis, 4(2), 229-239.

Kumar, A., \& Somani, A. (2020). Dealing with Corona virus anxiety and OCD. Asian Journal of Psychiatry.

Maria, I., Wijaya, V. \& Keni. (2021). Pengaruh Information Quality dan Service Quality terhadap Perceived Value dan Konsekuensinya terhadap Customer Engagament Behavior Intention (Studi pada Social Commerce Instagram. Jurnal Muara Ilmu Ekonomi dan Bisnis, 5(2), 321-334.

Nguyen et al. (2020). Online Book Shopping in Vietnam: The Impact of the COVID-19 Pandemic Situation. Springer.

Omer, M. (2021). Pandemic Covid-19: Impact On Digital Marketing. Journal Of Contemporary Issues In Business And Government, 27(4), 131-138.

Pandey, R. (2020). Dampak COVID19 pada Kesiapan Teknologi dan Penerimaan Teknologi di Kampus. Jurnal Kajian Ilmiah (JKI), 1, 107-116.

Qiu, W., Chu, C., Mao, A., \& Wu, J. (2018). The impacts on health, society, and economy of SARS and H7N9 Outbreaks in China: A Case Comparison Study. Journal of Environmental and Public Health. 
Sarstedt, M., Ringle, C. M., \& Hair, J. F. (2017). Partial least squares structural equation modeling. Springer International Publishing. Hamburg.

Sawicki, A. (2016). Digital Marketing. World Scientific News, 48, 82-88.

Sekaran, U., \& Bougie, R. (2016). Research Methods for Business: A Skill Building Approach. Edisi ke-7, Wiley. New Jersey.

Tenenhaus, Michel, et al. (2004). PLS Path Modelling. Elsevier Journal Computation Statistics \& Data Analysis.

Todor, R. D. (2016). Blending traditional and digital marketing. Bulletin of the Transilvania University of Braşov, 9(58), 51-56.

Triyoga, H. \& Sodiq, F. (2021). Dampak Pandemi COVID-19, Belanja Iklan Televisi Alami Penurunan. URL: https://www.viva.co.id/berita/nasional/1360752-dampak-pandemicovid-19-belanja-iklan-televisi-alami-penurunan. Diakses tanggal 16 Agustus 2021.

Tumer, et al. (2019). The impact of traditional and social media marketing on customers' brand trust and purchase intentions in the Turkish airline market. Journal of Research in Emerging Markets, 1(4), 55-68.

Wetzels, M., Odekerken-Schröder, G., \& Van Oppen, C. (2009). Using PLS path modelling for assessing hierarchical construct models: guidelines and empirical illustration. MIS Quarterly, 33(1), 177-195.

Yuvaraj, S., \& Indumathi, R. (2018). Influence of Digital Marketing on Brand Building. International Journal of Mechanical Engineering and Technology (IJMET), 9 (7), 235243. 